\title{
The Proliferation of Small Arms and Light Weapons in Nigeria: Corruption a Major Challenge
}

\author{
Salisu Malami \\ Nor Anita Abdullah \\ ZuRYaTI MOHAMED YusofF
}

\begin{abstract}
The proliferation of small arms and light weapons (SALW) is gradually and perilously becoming a transnational organized crime. In Nigeria, this peril assumed its delicate stage with incessant killings by Boko Haram insurgents, herdsmen-farmers clashes, kidnappings, communal and religious crisis, and armed robbery. The drift of this threat is the availability of weapons that are trafficked through Nigeria's porous borders. Regulating the proliferation of small arms and light weapons has been challenged by several factors such as border porosity, inadequate personnel, lack of equipment, lack of data, weak enforcement, stockpile management, local arms manufacturers. Corruption takes center stage and is the focus of this paper. Corruption directly or indirectly is related to other challenges. The paper recommends that corruption must be addressed if all legal and institutional measures for border security and curtailing the spread of weapons in Nigeria are to achieve their objectives.
\end{abstract}

Keywords: Corruption; security; small arms and light weapons; proliferation; Nigeria

\section{INTRODUCTION}

The challenges of corruption in Nigeria have become extremely rampant, and previous governments in the country have come to realise the problem displayed by corruption to the nation's security architecture. It generally pervades all regions in the country and in the words of famous scholar Achebe "anyone who can say that corruption in Nigeria has not yet become alarming is either a fool, a crook or else does not live in the country."1

For many decades, public and private establishments in Nigeria are categorised basically by ineffectiveness and inefficiency. This condition is not different in other African countries. Widespread corruption has been recognised as one of the key causes of Nigeria's underdevelopment, poverty, and rising crimes rate. ${ }^{2}$ Furthermore, organised crime support corruption and equally corruption promote crime. ${ }^{3}$ In addition to its social and economic impact, corruption facilitates and augment crimes as transnational trafficking in persons, drugs and illicit small arms that exhibit grievous threat to security in Nigeria. This paper examines the negative effect of corruption on small arms and light weapons proliferation in Nigeria. Hence the paper is divided into five sections. Section one covers the introduction. Section two treats basic concepts such as corruption, SALW, and proliferation and methodology. While section three deals with the role of security agencies in promoting corruption. Section four expose some factors that aid corruption and SALW proliferation. Finally, section five deals with conclusion.

\section{CONCEPTUAL CLARIFICATIONS}

\section{CORRUPTION}

The term corruption emanates from the Latin word 'rumpere' (to break), indicating that something is fragmented. ${ }^{4}$ The broken thing might be social or moral code of conduct, mostly, an administrative regulation. Onuaha defines it as an unlawful act, which comprises inducement and or undue influence of people either in the public or private setting to act contrary to the extant rules and regulations which normally guide a particular process. ${ }^{5}$

According to Olugbenga, Odofin, and Omojuwo, corruption cannot be easily defined. ${ }^{6}$ However, other scholars such as Ajibewa, Falore, and Igbuzor argue that defining corruption is a difficult, daunting, and challenging task. ${ }^{7}$ Nevertheless, Andrig and Fjelsad sight corruption as a "complex and multifaced phenomenon with multiple causes and effects, as it takes on various forms and contexts." "To them, one of the key problems in theorising corruption is the fact that it is tough to vanish. However, it can take a different dimension. ${ }^{9}$ In the same vein, 
defining corruption is difficult but recognizing its consequences are apparent.

In addition to the above, the United Nations Global Programme against Corruption (GPAC) defines it as "abuse of power for private gain." 10 Transparency International has chosen a clear and focused definition of the term as "the abuse of entrusted power for private gain." It can also be defined as a pervasion or change from the generally accepted rules or laws for selfish gain. ${ }^{11}$ According to Wells and Hymes, "corruption is a universal phenomenon that is not peculiar to any race, belief, political system or location. It traces have widespread all over the globe. The root of corruption has been found in ancient civilizations, including the founding fathers of modern democracy". ${ }^{12}$

\section{SMALL ARMS AND LIGHT WEAPONS}

The term small arm and light weapon from now on referred to as "SALW" has been defined by different legal and non-legal legislations/instruments. A careful observation at the several descriptions to the term "SALW" reveals a broader scope of weapons, ammunition, and their components. While there is no single globally accepted definition of the term SALW, the report of the United Nations panel of Government Experts on small arms in 1997 considers as thus:

\footnotetext{
"Weapons are ranging from clubs, knife, and machete, to those weapons just below those covered by the United Nations Register of Conventional Arms, for instance, mortars below the caliber of $100 \mathrm{~mm}$. The small arms are those weapons manufactured to military specification and designed for use by the one person. Whereas light weapons are those weapons used by several persons working as a crew." ${ }^{13}$
}

In addition to the above, the Bureau of Political Military Affairs of the US Department of state describes SALW "as encompassing manportable firearms and their ammunition primarily designed for individual use by military forces as lethal weapons." Moreover, a typical list of small arms would include carbines, self- loading pistols, assault rifles, submachine guns, and light machine guns capable of being handled by an individual. ${ }^{14}$ Laurence views small arms on a user's perspective, as those arms that can be moved in a vehicle, or by an infantry soldier or pack of animals. ${ }^{15}$ Furthermore, Onuoha describes SALW as any weapon that can be maneuvered and manipulated by one or two persons. ${ }^{16}$ Similarly, Eloma et- al defines small arms as firearms designed to be apprehended in one or both hands while being fired. ${ }^{17}$

\section{PROLIFERATION}

Proliferation denotes a sudden increase in the number or amount of an entity. If used in other frameworks, it implies rapid expansion, abundance, or multiplication. When used about SALW, it connotes the spread of the weapons, mostly, from one state to another or from state to non-state actors. ${ }^{18}$ The above concept also means the spread of SALW from a specific group of owners to another. Scholars such as Ogaba define proliferation as the excessive accumulation and illegal spread of weapons which could have a destabilising effect on states. ${ }^{19}$ Certain intermediaries facilitate the spread of SALW as a means of proliferation or multiplication about licit and illicit demands. The Graduate Institute of International Studies, Geneva observes that:

"Small arms and light weapons do not proliferate by themselves. They are sold, resold, perhaps stolen, diverted, and may be legally or illegally transferred several more times. At each junction in this complex chain of legal and illicit transfer, people- brokers, insurgents, criminals, government official and or organized groups are active participants in the process. ${ }^{20}$

The United Nations agreed that enormous procurement and gathering of weapons by a state or non-state actor could augment proliferation. Nevertheless, for accumulation to be capable of increasing proliferation, it has to be "excessive" and "destabilising." This position was supported by the report of the Panel of Government Expert on Small Arms (1997), it provides that:

"The mere accumulation of weapons is not sufficient criterion by which to define an accumulation of weapons as excessive or destabilising, since a large number of weapons that are under the strict and effective control of a responsible State does not necessarily lead to violence. Conversely, a small number of weapons can be destabilising under certain conditions." ${ }^{21}$

\section{METHODOLOGY}

The methodology adopted for this paper is sociolegal. It is a combination of doctrinal research method known in law with an empirical approach. Semi-structured interviews were conducted with four respondents to know how corruption increases the proliferation of SALW in Nigeria. The perspective of the respondents in the area of research complemented the existing literature. 
Where appropriate, the analysis will be supported by sufficient excerpts.

\section{CORRUPTION IN SECURITY INSTITUTIONS}

The leading agencies charged with the responsibility of security in Nigeria are the Nigeria Police, the Custom, the Immigration, and the Army. In many countries, Nigeria inclusive, the police have been the key establishment saddled with the duty of maintenance of law and order. Effective policing is, therefore, necessary for every society for the sustenance of peace. This indicates that maintenance of peace does require not only safeguarding life and property but also embraces the prevention and detection of crimes and enforcement of the law. Though, in discharging its duties, the Nigeria police are challenged with a series of problems, topmost is corruption, which always affects their actual role..$^{22}$

In the past, there was an effort by the country to regulate the threat of corruption. This led to the endorsement of the United Nations Convention Against Corruption 2003 in Mexico City. ${ }^{23}$ Regardless of the presence of these beautiful legal instruments and policies against corruption, Nigeria appears to have failed woefully in fighting corruption. A leading global nongovernmental organization on corruption Transparency International (TI) at so many occasions rated Nigeria low in fighting corruption. In 2012, for instance, TI rated Nigeria the $35^{\text {th }}$ most corrupt country globally. Similarly, the recent survey report conducted in 2017 by the United Nation Office of Drugs and Crime in collaboration with National Bureau of Statistic confirms that Nigeria police ranked highest in bribery taking among the country's public institutions with 46.6 percent. ${ }^{24}$ In a more recent report conducted in 2018 by the Socio-Economic Right and Accountability Project (SERAP), among the major public institutions in Nigeria police emerge the most corrupt in the country. The report reveals that "a bribe is paid in $54 \%$ of interactions with the police". In reality, an average of $63 \%$ of Nigerians was asked to give a bribe while dealing with police. ${ }^{25}$ These regulatory challenges have led to the increase of security gaps, which resulted in the use of private security guards.

Corruption exacerbates the spread of SALW. ${ }^{26}$ Furthermore, it was revealed that in September 2017, the Nigerian police force arrested two police corporals for selling revolver pistol to bandits, murderers, and kidnappers. The suspects have paraded at zone 9 Police Headquarters before charging them to court. ${ }^{27}$ In the same vein, citizens are now more concerned about the whole country over the perceived corruption of the Nigeria police. This leads to the police inability to deal with the heighten proliferation of SALW and other crimes in the country.

Corruption creates a security contradiction that promotes the cycle of SALWs proliferation in Nigeria. Corruption has become institutionalized in the country, and the security sector has turned out to be corrupt. Looking at the rise in poverty and low wages of security agents, some unpatriotic and greedy security officials are easily corrupted by global arms traffickers in Nigeria. To move their SALW without detection, arms traffickers. This is a critical issue which impact affects socioeconomic wellbeing of the country. Although Nigeria earns millions of Dollars as revenue from oil, unfortunately, many of its citizens live below the poverty line as they earn and or spend less than 1.25 USD per day. ${ }^{28}$ In regulating the proliferation of illegal weapons, previous researches conducted reveals that corruption significantly adds to the illegal weapons trade worldwide. ${ }^{29}$ Corruption relating to weapons trade contributes virtually $50 \%$ of the entire corruption in the world. ${ }^{30}$ In Nigeria, corruption among security agencies such as custom, police, and military is a known factor that exacerbates the proliferation of weapons. This is because security personnel was accused of arms leakages and corruption in numerous instances. ${ }^{31}$ As they are reported to have sold government official firearms to criminals. ${ }^{32}$ In, for instance, a report carried out by the office of the Auditor General of the Federation in 2016/2017 discloses that many firearms belongings to the Nigeria Police could not be traced. According to Nwanze - a security expert, there could be a link between disappearances of the police arms and sources of arms used in cattle rustling, armed robbery, and kidnapping. Respondent 4 said:

"The calamitous selling of weapons by security personnel to the group of bandit and insurgent is attributed to the enormous nature of corruption in the security architecture of Nigeria. I am aware of a case were military personnel was caught selling live ammunitions to Boko Haram insurgents, and equally mindful of a reported case of selling of information to the insurgents for money."

\section{ANALYSIS OF EMPIRICAL FINDINGS}

As highlighted above, the qualitative analysis reveals various challenges militating against effective control of SALW proliferation in Nigeria. These problems include border porosity, local 
manufacturers, weak enforcement, inadequate personnel, lack of equipment, etc. However, corruption takes precedence over all other challenges as it directly or indirectly related to the other challenges. Furthermore, majority of the respondents agreed that corruption constitutes a significant challenge for SALW proliferation. The key challenges are briefly examined below.

\section{INADEQUATE AND CORRUPT PERSONNEL}

Corruption is a severe problem in the Nigerian security setting. As it percolates through all levels of the security establishment and manifests itself in diverse forms. ${ }^{33}$ It aids criminality and the proliferation of small and light arms. Apart from the porous borders, law enforcement agents are known to be corrupt. ${ }^{34}$ The participants, such as respondents 1, 2, 3, and 4 also highlighted corruption as a contributor to the proliferation of small arms and the rising criminality in Nigeria. According to respondent 1:

"There is a problem of corruption. People and law enforcement agencies strive to enrich themselves. These corruption tendencies have rendered the efforts for the reduction in the proliferation of SALW difficulty. This is a major challenge. Also, the quality of some of the officers assigned for this responsibility is considerably low." ${ }^{35}$

\section{Respondent No. 1 stated that:}

"But in fairness to security agencies we have a very porous border that is very difficult or impossible to restrict the importation of arms by the people who may wish to do so because land border, the sea border, and the activities involved and perhaps the issue of corruption has facilitated the import and Nigeria is well known for corruption. However, the current administration is making an effort to restore sanity in our own system." ${ }^{36}$

Bribery and corruption may take long to be eradicated at the borders as the offices are in some occasions and at some border posts expected to make returns of the share of the proceeds of bribe to the head office or the posting officers. Responding on this issue, respondent 1 stated that "in addition to this, some border officials are expected to share the returns with their superior officers back at the office further encouraging the cycle of corruption." ${ }^{37}$

\section{BORDER POROSITY}

The porosity of the Nigerian borders is among the key components promoting the proliferation of illicit SALW and crime in the country. ${ }^{38} \mathrm{~A}$ prominent arms trade expert Hartung contend that series of conflicts and other insecurity in Africa have attracted SALWs transaction and inflow of weapons to different parts of Africa that have closeness with Nigeria. ${ }^{39}$

These illicit border routes are mostly unidentified by security agencies, are unmanned, unprotected and thus serve as leaky routes for SALWs and ammunitions trafficking into Nigeria. It is frightening and unfortunate that the merchants of death have since created procedures use to deceived security agencies at the borders and through the footpaths. These methods include the use of camels, donkeys, and cows to traffic arms, ammunition and drugs, like cocaine into Nigeria.

Tight border controls are a fundamental means of reducing the proliferation of arms, especially small and light weapons. Many scholars such as Abdullahi, ${ }^{40}$ Hazen and Horner, Babatola ${ }^{41}$, attributed proliferation of SALW in Nigeria to lengthy and porous borders. ${ }^{42}$ This position has been confirmed by several of the respondents involved in this research. These include respondents 1,2 , 34 , and 5. According to respondent 5, "our land borders are porous. The porosity of this borders is equally a challenge more especially during the dry season, everywhere is a route for the smugglers." ${ }^{43}$ Respondent 3 posits that apart from the myriad of other problems militating against the control of proliferation is corruption. In his words:

"There are other issues like corruption. A customs officer at the border would not mind you imported whatever weapon in so far you will settle him. He does not care what happens to the economy and the security of the country provided he is settled. Corruption and politics are among the challenges militating against the control of arms and contributing arms proliferation." 44

\section{STOCKPILE MANAGEMENT}

In Nigeria, weak stockpile management in public armories is a factor challenging the control and prevention of SALW proliferation, as numerous scholars observed that security in charge of securing public armories abandon, sells or giveaway government owns firearms and ammunition to bandits and insurgents. Literature has shown that at the beginning of Boko Haram insurgency in northeast Nigeria, their source of obtaining weapons was by breaking into the armories of security agencies, theft or purchase from the illicit market. The above averment was corroborated by the statement released by the Defence Headquarters through its Director Information Major General 
Chris Olukolade who affirms looting its armory where he said "we are taking measures to ensure that our armories are secured. We agree and are aware Boko Haram has stolen our arms". ${ }^{45}$ In addition to this, the Chief of Army Staff Lieutenant General Kenneth Minimah confirmed that most of the Boko Haram weapons were stolen. Furthermore, on the $21^{\text {st }}$ September 2004 insurgents attacked Gworza and Bama police divisions all in Borno State. The attack led to the death of many law enforcement officers and carting away of numerous arms and ammunitions. ${ }^{46}$ To further support the above assertion in 2017, the Nigeria police discovered that a police armorer sold 162 firearms and a whopping amount of ammunition to the groups of bandits. ${ }^{47}$ This is a clear indication of inadequate control of Public armories by proper regulations and procedure. ${ }^{48}$

Respondent 5 while ascribed weapons leakages to corruption, lack of staff training and the poor state of government armories:

"There are no systematic training programs and investment in the weapons life cycle, and ammunition surveillance practices are limited. Poorly maintained infrastructure and corruption make state-controlled weapons and ammunition prone to leakage, and they are accessible to organised crime groups and terrorists".

\section{WEAK ENFORCEMENT}

Laws are not only to be put in place, but they need to be enforced. Where laws, no matter how good they are drafted appear not to be enforced, they will not serve the purpose of the enactment of the laws. Good law poorly enforced can significantly undermine confidence and compliance. ${ }^{49}$ This position applies to the regime for the enforcement of SALW. The findings from the literature and responses from the interviews reveal that although laws such as the Firearms Act exist, but enforcement remains one of the big challenges. Respondents 2, 3, and 10, in particular, see enforcement as a major challenge. While respondent 10 contends that "enforcement of SALW related legislation is very poor" ${ }^{50}$ According to Hazen and Horner "even some of the existing national laws that have been put in place to support international and national regulation of small arms are poorly enforced and as a result largely ineffective in addressing illicit proliferation." ${ }^{51}$

Respondent 3 posted that:

"So, my assessment is that the laws exist. At my fingertips, I can recall the Firearms Act, the Robbery and Firearms Act and the fact that the office or arm of the executive the police are in charge of the licensing and this mandate is given to them by the law. So the law exists, but the only problem like in all other fields of an endeavor like I said is implementation and enforcement." ${ }^{52}$

The judicial system is the channel through which the criminals are tried for illegal possession and crimes that are related, are prosecuted. The criminal justice system is full of problems beginning from arrest, investigation to prosecution aided by corruption. According to respondent 6 ,

\begin{abstract}
"The leading problem is that people who are alleged to have committed firearms-related offenses rarely faced prosecution and punishment for their nefarious conducts due to corruption. I think if police and office of the will take issues of investigation and prosecution seriously, the state will secure more convictions of criminals and in turn, it will checkmate arms spread and serve as deterrence to intending criminals. We must do all that we can in the area of discreet investigation of cases. I can remember vividly that between 1990 to 1998 out of 12000 arrested hoodlums for illicit possession of firearms only 500 amounting to (4.2) were successfully prosecuted."
\end{abstract}

\section{ARMORY BREAK AND ARMS THEFT}

Armory break and theft of weapons is a challenge and a major source of illicit SALW proliferation in Nigeria. ${ }^{53}$ This problem is not peculiar to Nigeria as it affects other advance jurisdictions such as the United States of America. A report from Gun Violence Prevention reveals that in the US, a gun is stolen every two minutes, and between 2012 to 2015, an estimated 1.2 million guns were stolen within the period. $^{54}$

The Nigeria case is more devastating as cases of arms theft, and armory break keeps on repeating itself. Between 1998 to 2000, over 196 firearms were reported missing by the Nigeria Police Force in Delta State alone. ${ }^{55}$ Similarly, the Nigeria Customs Service armory was also broken into, and a substantial number of firearms was stolen by unidentified bandits. Moreover, the unfortunate killing of about 20 Nigerian soldiers and the theft of their firearms at Zaki Biam town in Taraba State further confirmed firearms cases in Nigeria.

Recently in Kenya bandits broke into the police station and stole rifles and ammunition. The police officers on duty negligently left their duty post and went to the nearby trading center. ${ }^{56}$ In Papua New Guinea, for instance, the statistic has shown that $30 \%$ of police firearms were stolen and fall into the hands of bandits. ${ }^{57}$ It is common among many insurgent groups in West Africa. For example, the National Patriotic Front of Liberia and the Revolutionary United Front (RUF) of Sierra Leone received a supply of weapons before the arms conflict and at 
the eve to the outbreak of violence but continue to obtain the weapons supply during the war through theft and seizure. ${ }^{58}$ In South Africa theft of police, guns are ascribed to institutional failure. The statistic has shown that a huge amount of over 2000 firearms were stolen from South African Police between 2014 to 2017 . Within the period a total of 2027 guns were stolen while commenting on the threat Mrs. Dianna Kohler Barnard, a member of the parliament said "the reality is that the police are fueling the illegal arms trade. Thousands of South African police firearms have been stolen over the past 20 years and are out there in the hands of criminals shooting at the police and you and me".

She went further to state the genesis of the challenge and recommendation to the problem. She said:

"This is the result of institutional failure at the South African police. I believe that to ensure professional policing the police must ensure all member receive adequate, quality training on professional policing that is continually updated and refreshed, introduce a successful and viable system of accountability, making it easy to report police negligence corruption and ineffectiveness which can then be dealt with swiftly and appropriately, make police members pay for firearms they lose, and dismiss repeat offenders." 59

\section{GLOBAL AND NATIONAL LEGAL APPROACH TO CORRUPTION}

Realizing the adverse impact of corruption on the efficacy of global SALW control and arms trade, some legally binding global instruments such as the United Nations Convention against Corruption (UNCAC) 2005 were specifically devoted to contend corruption. Similarly, the United Nations Transnational Organized Crime (UNTOC) 2000 classified both corruption and money laundering as acts of "Transnational Organized Crime." Moreover, a lot of global instruments regulating SALW proliferation made provisions that seek to control the menace of corruption in global arms transfer processes. For example, the Arms Trade Treaty (ATT) appreciate the importance of curtailing corruption in order to prevent the diversion of weapons. The treaty encourages explicitly State Parties to exchange information on corruption in weapons dealings. ${ }^{60}$ Article 11(5) provides:

\footnotetext{
"In order to better comprehend and prevent the diversion of transferred conventional arms covered under Article 2 (1), State Parties are encouraged to share relevant information on effective measures to address diversion. Such information may include information on illicit activities including corruption, international trafficking routes, illicit brokers, sources of illicit
}

supply, methods of concealment, common points of dispatch, or destinations used by organized groups engaged in the diversion."

Furthermore, Article 15(6) provides that "States Parties are encouraged to take national measures and to cooperate with each other to prevent the transfer of conventional arms covered under Article 2 (1) becoming subject to corrupt practices."

In Nigeria, there are numerous legislations promulgated to curtail the spread of corruption in the country. This includes the Criminal Code Act, the Code of Conduct Bureau and Tribunal Act, the Public Procurement Act, the Independent Corrupt Practices Commission, and the Economic and Financial Crimes Commission Act etc. However, the totality of this legislation was silent on corruption in a security setting. The laws in Nigeria need to provide specific provisions and stiffer punishments on corrupt practices that will control arms proliferation. The laws should establish guidelines and policy that will prevent corrupt security personnel from diverting government weapons. Where such happens, a stiffer penal that will serve a deterrence shall be applied.

Some of the respondents contend that weapons smugglers can pass through Nigerians porous borders by just paying the security officials. The unlawful crossings cost not as much as the lawful routes. To justify their actions, some border security officials alleged that they are collecting the bribe because the government does not pay them hardship posting allowance, and poor salary, among others. Similarly, they further aver that lack of basic working instruments like torchlight, accommodation, and camp bed necessitates their actions. In addition to this, some border officials are expected to share the returns with their superior officers back at the office, further encouraging the cycle of corruption.

\section{CONCLUSION}

Corruption is a menace in Nigeria. It pervades the public and private space. It is, however, prominent in public or government circles. Corruption is a serious problem militating against the prevention and control of small and light weapons in Nigeria. Doctrinally and empirically it has been documented as a leading challenge in combatting transnational crimes such as arms trafficking and smuggling. The recent arrests of a cache of arms at the ports and compromise of security agencies are instructive. Corrupt activities in Nigeria has become a scourge to all kind of development and apparently threaten 
national security. It must be tackled by strengthening institutions and feasible legislation without further delay. The legislation shall provide stiffer penalties for anyone found guilty of corrupt practices, particularly security personnel. Where a security agent is found to have breached a trust, engage in corruption by leaking information to the insurgent and or selling or hiring weapons to them, he shall be punished with death on conviction. This will considerably control the prolonged illicit SALW deal in Nigeria. To reduce or prevent the proliferation of small and light weapons in Nigeria, corruption must be checked; otherwise, it would continue to undermine all the legal and institutional structures put in place in the country no matter how sound and important they may be in the control and prevention of SALWs proliferation.

\section{NOTES}

1 C. Achebe, The Trouble with Nigeria, 3rd Edn, Fourth Dimension Publishers, Enugu, 1983.

2 M. M. Adagbabiri \& U. C. Okolie, Corruption and the Challenges of Insecurity in Nigeria's Fourth Republic, Journal of Political Science and Leadership Research 4(3), 2018, p 41.

3 M. E. Beare, Corruption and Organized Crime: Lessons from History, Crime, Law and Social Change 28(2), 1997, p 5 .

4 C. Buck, A Theological Dictionary, Containing Definitions of All Religious Terms,5th Edn, W.W. Woodward, Philadelphia, 1980.

5 E. I., The Effective Administration of Criminal Justice for the Prevention of Corruption Activities by Public Officials. The Nigerian Position, Resource Materials Series 56, 2005, p 48.

6 A. P. Odofin \& K. A. Omojuwa, The Challenges of Democratisation Process in Nigeria, AY Sule Digital Printers, Zarla, 2007.

7 Anti-Corruption War in Nigeria, Strategies for Winning the Anti-Corruption War in Nigeria, Action Aid Nigeria Briefing Paper 2, 2008. See also O. O. Faloore, The Family and Corruption Management in Nigeria, Journal of Social and Policy Issues 7(2), 2010, p 84-89.

8 O. Fjeldstad, J. C. Andvig, I. Amundsen, T. Sissener \& T Søreide, Corruption. A Review of Contemporary Research, CMI Report R 2001, 2001, p 7.

9 Usman Mohammed, Corruption in Nigeria: A Challenge to Sustainable Development in the Fourth Republic, European Scientific Journal (ESJ) 9(4), 2013.

10 R. Babu, The United Nations Convention against Corruption: A Critical Overview, SSRN, 2006, p 6. https:// papers.ssrn.com/sol3/papers.cfm?abstract_id=891898 [31 October 2019].

11 Farida Waziri, Corruption and Governance Challenges in Nigeria, in Nigeria Fiscal Agenda for Change Public Expenditure Management and Financial Accountability, Cleen Foundation, Abuja, 2006.

12 J. T. Wells \& L. Hymes, Bribery and Corruption Casebook: The View from Under the Table, John Wiley \& Sons, 2012.
13 C. F. Chigozie, Nigeria and the Ecowas Convention on Small Arms and Light Weapons: A Critical Appraisal, Master Thesis. Department of Political Science, University of Nigeria. 2010. p 8. See also Report of the Panel of Governmental Experts on Small Arms (A/52/298), United Nations Office for Disarmament Affairs, 2000. https:// www.un-ilibrary.org/content/books/9789210584913c001 [31 October 2019]

14 M. Renner, Curbing the Proliferation of Small Arms, The World Watch Institute.www.worldwatch.org/node/3738 [31 October 2019]

15 V. U. Okoro, The Proliferation of Small and Light Weapons in West Africa: Implication for Sub Regional Security, United States Army Command and General Staff College, 1994.

16 G. Onuoha, Contextualizing the Proliferation of Small Arms and Light Weapons in Nigeria, African Security Review 15(2), 2006, p 3.

17 E. E. Usang, N. F. C. Ugwumba \& E. O. Abang, Effect of Proliferation of Small Arms and Light Weapons on the Development of the Niger Delta Region of Nigeria, Journal of Developing Country Studies 4(10), 2014.

18 M. R. Ventura, Arms Control and Disarmament: Legitimacy, War, and Peace, Macalester College, 2018.

19 O. Oche, The Proliferation of Small Arms and Light Weapons, Fog Ventures, Lagos, 2005.

20 Anwarul Karim Chowdhury, United Nations Conference on the Illicit Trade in Small Arms and Light Weapons in All Its Aspects, in Conference on Illicit Trade on Small and Light Weapons, New York, 2001, p 1. http://www. worldwatch.org/node/3738 [31 October 2019]

21 M. Donowaki, United Nations Panel of Group of Experts on Small Arms, New York, 2001. https://www.un.org/ Depts/ddar/Firstcom/SGreport52/a52298.html October 2019]

22 B. O. Osayande, Factors Inhibiting Police Performance in Nigeria, A Paper Presented At The Occasion of the Retreat With the Theme: Understanding the Mandate and Operations of the Police Service Commission in Context of the Rule of Law, 2008, p 14. See also N. D. Nte, Police Corruption and the National Security Challenge in Nigeria: A Study of Rivers State Police Command, International Journal of Human Sciences 8(1), 2011, p 548.

23 A. Argandoña, The United Nations Convention against Corruption and Its Impact on International Companies, Journal of Business Ethics 74(4), 2007, p 1.

24 Rating of Nigeria Police Worst Globally, Punch Newspaper. Lagos, 2017.

25 A. Bamgboye, Police Most Corrupt Institution in Nigeria, Daily Trust, 2019. https://dailytrust.com/police-mostcorrupt-institution-in-nigeria-serap-survey $\quad[27$ March 2019]

26 V. O. S. Okeke \& R. O. Oji, The Nigerian State and the Proliferation Small Arm and Light Weapons in the Northern Part of Nigeria, Journal of Educational and Social Research 4(1), 2014, p 426.

27 Police Arrest 2 Officers Selling Guns to Robbers, Kidnappers, Sahara Reporters, http://saharareporters. com/2017/10/05/police-arrest-2-officers-selling-gunsrobbers-kidnappers, 2017 [31 October 2019]

28 I. A. Nnenna, Rising Inequality and the Challenge of Change in Nigeria, International Journal of Humanities and Social Sciences 4(9), 2014, p 209. 
29 E. Gutterman \& A. Lane, Beyond LAVs: Corruption, Commercialization and the Canadian Defence Industry, Canadian Foreign Policy Journal 23(1), 2017, p 77-92.

30 E. Henriksson, Corruption in the Arms Trade, International Peace Bureau, 2007. p 17. https://www.ipb.org/wpcontent/uploads/2017/03/here.pdf [31 October 2019]

31 S. O. Ehiane \& D. D. Uwizeyimana, Challenges in Combating the Proliferation of Small Arms and Light Weapons (SALW) in Nigeria: A Human Security Perspective, Journal of African Foreign Affairs 5(3), 2018, p 79.

32 A. N. Ayissi \& S. Ibrahima, Combating the Proliferation of Small Arms and Light Weapons in West Africa: Handbook for the Training of Armed and Security Forces, (United Nations Publications UNIDIR, 2005.

33 African Report, Nigeria: The Challenges of Military Reforms, Brussels, 2016.

34 Salisu Malami, Nor Anita Abdullah \& Zuryati Mohamed Yusoff, Legal and Regulatory Challenges for the Proliferation of Small and Light Weapons in Nigeria, School of Social Sciences, USM, p 81.

35 Interview with respondent 1 at his Office, Department of Criminology, Faculty of Social Sciences, Bayero University Kano, Nigeria on April 3, 2018.

36 Interview with respondent 1 at his Office, Department of Criminology, Faculty of Social Sciences, Bayero University Kano, Nigeria on April 3, 2018.

37 Interview with respondent 3 at his Office, Department of Public Law, Faculty of Law, Bayero University Kano, Nigeria, on April 32018.

38 J. E. T. Babatola, Challenges of Nigeria's Border and Frontier Security 1960-2014, Friedrich Ebert Stiftung, Abuja, 2015, p 9. See also A. S. Ademola, Porous Border, Small Arms Proliferation, and Insecurity in Oke- Ogun Area of Oyo State, Nigeria, International Journal of Research and Innivation in Social Science 3(1), 2019, p 88 .

39 J. K. Ukwayi \& B. E. Anam, Cross- Border Crime and Security Challenges in Nigeria, International Journal of Scientific Research in Humanities, Legal Studies and International Relations 4(1), 2019, p 108.

40 Abdullahi Ibrahim, The State of Proliferation of Small Arms and Light Weapons in Sub-Saharan Africa: Regional, State and Local Causes, International Journal of Business \& Law Research 4(3), 2016, p 31.

41 J. E. T. Babatola, Challenges of Nigeria's Border and Frontier Security 1960-2014.

42 J. M. Hazen \& J. Horner, Small Arms, Armed Violence and Insecurity in Nigeria: The Niger Delta in Perspective, Small Arms Survey, Geneva, 2007. See also Zuryati Mohamed Yusoff, Salisu Malami \& Nor Anita Abdullah, Effective Border Security: A Strategy for Curtailing Arms Proliferation in Nigeria, International Journal of Interlectual Discourse 1( ), 2019, p 197.

43 Interview with respondent 5 at his office Federal Secretariat, Federal Capital Territory Abuja, Nigeria.

44 Interview with respondent 3 at his Office, Department of Public Law, Faculty of Law, Bayero University Kano, Nigeria on April 3, 2018

45 N. Okeke, Boko Haram Loots Our Armoury, Says Defence Headquarters, Naij.Com, 2014. http://www.legit. ng/298333-boko-haram-loots-army-armoury.html [8 April 2019]
46 R. S. Olasile, Boko Haram: The Menace of Small Arms and Light Weapons Proliferation in Nigeria, International Academic Journal of Educational Research 1(1), 2015, p 19.

47 S. Folarin, Lagos Police Armourer Sells Arms to Militants, Attempt Suicide, Punch Newspaper, 2017.

48 J M. Moses \& J. L. Ngomba, Small Arms and Light Weapons Proliferation in the Early 21st Century: The Nigerian Case, International Journal of Development and Sustainability 6(11), 2017, p 1645. See also Abdullahi Ibrahim, Contextualizing the Proliferation of Small Arms and Light Weapons in Nigeria: The Untold Story, International Journal of Business and Law Research 3(1), 2015, p 10 and. G. Tomasevic \& M. Dickson, Phsical Security and Stockpile Management: Lesson Learned From Ivory Coast, The Halo Trust, 2015, p 4.

49 K. Cravero, How to Guide Small Arms and Light Weapons Legislation, Bureau Crisis Prevention and Recovery 21, 2008.

50 Interview with respondent 10.

51 J. M. Hazen \& J. Horner, Small Arms, Armed Violence and Insecurity in Nigeria: The Niger Delta in Perspective, Geneva, 2007.

52 Interview with respondents 3 at his Office, Department of Public Law, Faculty of Law, Bayero University Kano, Nigeria, on April 3, 2018

53 N. Duquet, Arms Acquisition Patterns and the Dynamics of Armed Conflict: Lessons from the Niger Delta, International Studies Perspectives 10(2), 2009, p 212.

54 C. Parsons \& E. W. Vargas, Stolen Guns in America: A State by State Analysis, Centre for American Progress, 2017. https://www.americanprogress.org/issues/gunscrime/reports/2017/07/25/436533/stolen-guns-america/ [23 July 2021]

55 V. O. Anyim, Contending Issues in Small Arms Proliferation and Violence in Nigeria, Nnamdi Azikiwe University Journal of International Law 5(2), 2013, p 16.

56 Anon. 2019. Robbers Break into Police Station, Steal Rifles Ammunitions as Officers Watch UEFA Match, Vanguard.

57 World Health Organization, Violence Prevention: The Evidence, 2010, p 3. https://apps.who.int/iris/ handle/10665/77936 [23 July 2021]

58 F. L. Keili, Small Arms and Light Weapons Transfer in West Africa: A Stock Taking, Geneva, 2008. http://www. unidir.org/files/publications/pdfs/the-complex-dynamicsof-small-arms-in-west-africa-en- [31 October 2019]

59 D. K. Barnard, Over 2000 Guns Stolen From SAPS Armouries in 4 Years, The Democratic Alliance, 2017. https://www.da.org.za/2017/10/2000-guns-stolen-sapsarmouries-4-years [31 October 2019]

$60 \quad$ Article 11 (5) and Article 15 (6) ATT 2005.

\section{REFERENCES}

Abdullahi Ibrahim. 2015. Contextualizing the proliferation of small arms and light weapons in Nigeria: The untold story. International Journal of Business and Law Research 3(1).

Abdullahi Ibrahim. 2016. The state of proliferation of small arms and light weapons in Sub-Saharan Africa: Regional, state and local causes. International Journal of Business \& Law Research 4(3): 31. 
Achebe, C. 1983. The Trouble with Nigeria. $3^{\text {rd }}$ edition. Enugu: Fourth Dimension Publishers.

Adagbabiri, M. M. \& Ugo Chuks Okolie. 2018. Corruption and the challenges of insecurity in Nigeria's fourth republic. Journal of Political Science and Leadership Research 4(3): 41 .

Ademola, A. S. 2019. Porous border, small arms proliferation, and insecurity in Oke- Ogun Area of Oyo State, Nigeria. International Journal of Research and Innovation in Social Science 3(1): 88.

African Report. 2016. Nigeria: The Challenges of Military Reforms. Brussels.

Anon. 2017. Rating of Nigeria police worst globally. Punch Newspaper.

Anon. 2019. Robbers break into police station, steal rifles ammunitions as officers watch UEFA match. Vanguard.

Anti-Corruption War in Nigeria. 2008. Strategies for winning the anti-corruption war in Nigeria. Action Aid Nigeria Briefing Paper 2.

Anwarul Karim Chowdhury. 2001. United Nations Conference on the illicit trade in small arms and light weapons in all its aspects. In Conference on Illicit Trade on Small and Light Weapons, New York. http:// www.worldwatch.org/node/3738 [31 October 2019]

Anyim, V. O. 2013. Contending issues in small arms proliferation and violence in Nigeria. Nnamdi Azikiwe University Journal of International Law 5(2): 16.

Argandoña, A. 2007. The United Nations Convention against corruption and its impact on international companies. Journal of Business Ethics 74(4): 1.

Ayissi, A. N. \& Ibrahima, S. 2005. Combating the Proliferation of Small Arms and Light Weapons in West Africa: Handbook for the Training of Armed and Security Forces, United Nations Publications UNIDIR.

Babatola, J. E.T. 2015. Challenges of Nigeria's Border and Frontier Security 1960-2014. Abuja: Friedrich Ebert Stiftung.

Babu, R. 2006. The United Nations Convention against Corruption:ACritical Overview. SSRN. https://papers. ssrn.com/sol3/papers.cfm?abstract_id $=891898 \quad$ [31 October 2019].

Bamgboye, A. 2019. Police most corrupt institution in Nigeria. Daily Trust. https://dailytrust.com/policemost-corrupt-institution-in-nigeria-serap-survey [27 March 2019]

Barnard, D. K. 2017. Over 2000 guns stolen from SAPS armouries in 4 years. The Democratic Alliance. https://www.da.org.za/2017/10/2000-guns-stolensaps-armouries-4-years [31 October 2019]

Beare, M. E. 1997. Corruption and organized crime: Lessons from history. Crime, Law and Social Change 28(2): 5 .

Buck, C. 1980. A Theological Dictionary, Containing Definitions of All Religious Terms. $5^{\text {th }}$ edition. Philadelphia: W.W. Woodward.
Chigozie, C. F. 1997. 2010. Nigeria and the Ecowas Convention on Small Arms and Light Weapons: A Critical Appraisal. Master Thesis. Department of Political Science, University of Nigeria.

Cravero, K. 2008. How to Guide Small Arms and Light Weapons Legislation. Geneva, Bureau Crisis Prevention and recovery 21.

Donowaki, M. 2001. United Nations Panel of Group of Experts on Small Arms. New York. https://www. un.org/Depts/ddar/Firstcom/SGreport52/a52298. html.

Duquet, N. 2009. Arms acquisition patterns and the dynamics of armed conflict: Lessons from the Niger Delta. International Studies Perspectives 10(2): 212.

Ehiane, S.O. \& Uwizeyimana, D.D. 2018. Challenges in combating the proliferation of Small Arms and Light Weapons (SALW) in Nigeria: A human security perspective. Journal of African Foreign Affairs 5(3): 79.

Faloore, O. O. 2010. The family and corruption management in Nigeria. Journal of Social and Policy Issues 7(2): 84-89.

Farida Waziri. 2006. Corruption and governance challenges in Nigeria. In Nigeria Fiscal Agenda for Change Public Expenditure Management and Financial Accountability. Abuja: Cleen Foundation.

Fjeldstad, O., Andvig, J. C., Amundsen, I., Sissener, T. \& Søreide, T. 2001. Corruption. A review of contemporary research. CMI Report R 2001: 7.

Folarin, S. 2017. Lagos police armourer sells arms to militants, attempt suicide. Punch Newspaper.

Gutterman, E. \& Lane, A. 2017. Beyond LAVs: Corruption, commercialization and the Canadian defence industry. Canadian Foreign Policy Journal 23(1): 77-92.

Hazen, J. M. \& Horner, J. 2007. Small Arms, Armed Violence and Insecurity in Nigeria: The Niger Delta in Perspective. Geneva: Small Arms Survey.

Henriksson, E. 2007. Corruption in the Arms Trade. International Peace Bureau. https:/www.ipb.org/wpcontent/uploads/2017/03/here.pdf

Ibrahim Abdullahi. 2015.Contextualizing the proliferation of small arms and light weapons in Nigeria: The untold story. International Journal of Business and Law Research 3(1): 10.

Keili, F. L. 2008. Small Arms and Light Weapons Transfer in West Africa: A Stock Taking. Geneva. http://www.unidir.org/files/publications/pdfs/thecomplex-dynamics-of-small-arms-in-west-africa-en[31 October 2019]

Salisu Malami, Nor Anita Abdullah \& Zuryati Mohamed Yusoff. 2017. Legal and Regulatory Challenges for the Proliferation of Small and Light Weapons in Nigeria. Penang: School of Social Sciences, USM.

Moses, J. M. \& Ngomba, J. L. 2017. Small arms and light weapons proliferation in the early 21 st century: The Nigerian case. International Journal of Development and Sustainability 6(11): 1645. 
Nnenna, Idike Adeline. 2014. Rising inequality and the challenge of change in Nigeria. International Journal of Humanities and Social Sciences 4(9): 209.

Nte, N. D. 2011. Police corruption and the national security challenge in Nigeria: A study of rivers state police command. International Journal of Human Sciences 8(1): 548.

Oche, O. 2005. The Proliferation of Small Arms and Light Weapons. Lagos: Fog Ventures.

Odofin, A. P. and Omojuwa, K. A. 2007. The Challenges of Democratisation Process in Nigeria. Zarla: AY Sule Digital Printers.

Okeke, Nkem. 2014. Boko Haram loots our armoury, says defence headquarters. Naij.Com. http://www. legit.ng/298333-boko-haram-loots-army-armoury. html [8 April 2019]

Okeke, V. O. S. \& Oji, R. O. 2014. The Nigerian state and the proliferation small arm and light weapons in the northern part of Nigeria. Journal of Educational and Social Research 4(1).

Olasile, Raheem Sodiq. 2015. Boko Haram: The menace of small arms and light weapons proliferation in Nigeria. International Academic Journal of Educational Research 1(1): 19.

Okoro, V. U. 1994. The Proliferation of Small and Light Weapons in West Africa: Implication for Sub Regional Security. United States Army Command and General Staff College.

Onuoha, E. I. 2005. The effective administration of criminal justice for the prevention of corruption activities by public officials. The Nigerian position. Resource Materials Series 56: 48.

Onuoha, G. 2006. Contextualizing the proliferation of small arms and light weapons in Nigeria. African Security Review 15(2).

Osayande, B. O. 2008. Factors inhibiting police performance in Nigeria. A Paper Presented at the Occasion of the Retreat with the Theme: Understanding the Mandate and Operations of the Police Service Commission in Context of the Rule of Law: 14.

Police Arrest 2 Officers Selling Guns to Robbers, Kidnappers. 2017. Sahara Reporters. http:// saharareporters.com/2017/10/05/police-arrest-2officers-selling-guns-robbers-kidnappers, 2017 [31 October 2019]

Renner, M. 2019. Curbing the proliferation of small arms. The World Watch Institute.www.worldwatch.org/ node/3738 [31 October 2019]

Salisu Malami, Nor Anita Abdullah, Zuryati Mohamed Yusoff. 2019. Effective border security: A strategy for curtailing arms proliferation in Nigeria. International Journal of intellectual Discourse 1(2): 195.
Tomasevic, G. \& Dickson, M. 2015. Physical Security and Stockpile Management: Lesson Learned from Ivory Coast. The Halo Trust: 4.

Ukwayi, J. K. \& Anam, B. E. 2019. Cross-border crime and security challenges in Nigeria. International Journal of Scientific Research in Humanities, Legal Studies and International Relations 4(1): 108.

United Nations. 2000. Report of the Panel of Governmental Experts on Small Arms (A/52/298). United Nations Office for Disarmament Affairs. https://www.unilibrary.org/content/books/9789210584913c001 [31 October 2019]

Usang, 1. E. E., Ugwumba, N. F. C. \& Abang, E. O. 2014. Effect of proliferation of small arms and light weapons on the development of the Niger Delta Region of Nigeria. Journal of Developing Country Studies 4(10).

Usman Mohammed. 2013. Corruption in Nigeria: A challenge to sustainable development in the fourth republic. European Scientific Journal (ESJ) 9(4).

Parsons, C. and Vargas, E. W. 2017. Stolen Guns in America: A State by State Analysis, Centre for American progress. https://www.americanprogress. org/issues/guns-crime/reports/2017/07/25/436533/ stolen-guns-america/ [23 July 2021]

Ventura, Milo R. 2018. Arms Control and Disarmament: Legitimacy, War, and Peace. Macalester College.

Wells, Joseph T, and Laura Hymes. 2012. Bribery and Corruption Casebook: The View from Under the Table. John Wiley \& Sons.

World Health Organization. 2010. Violence prevention: The evidence. https://apps.who.int/iris/ handle/10665/77936 [23 July 2021]

Salisu Malami

Department of Law

Aminu Kano College of Islamic and Legal Studies

B.U.K Road, Kano, Nigeria.

Email: smalamilegal@gmail.com

Nor Anita Abdullah

School of Law, Government and International Studies

Universiti Utara Malaysia

Email: noranita@uum.edu.my

Zuryati Mohamed Yusoff

School of Law, Government and International Studies

Universiti Utara Malaysia

Email: zuryati@uum.edu.my 